\title{
Synthesis of 14-Substituted-14H-Dibenzo[ $a, j]$ Xanthene Derivatives in Presence of Effective Synergetic Catalytic System Bleaching Earth Clay and PEG-600
}

\author{
Sandeep T. Atkore ${ }^{1, *}$, Giribala M. Bondle ${ }^{2}$, Pranita V. Raithak ${ }^{3}$, Vinod T. Kamble ${ }^{4}$, Ravi Varala ${ }^{5}$ (D), \\ Mufsir Kuniyil $^{6}$ (D), Mohammad Rafe Hatshan ${ }^{6}$ D, Baji Shaik ${ }^{7}$, Syed Farooq Adil ${ }^{6, *(D)}$ \\ and Mohammed Althaf Hussain 8
}

Citation: Atkore, S.T.; Bondle, G.M.; Raithak, P.V.; Kamble, V.T.; Varala, R.; Kuniyil, M.; Hatshan, M.R.; Shaik, B.; Adil, S.F.; Hussain, M.A. Synthesis of 14-Substituted-14H-Dibenzo[ $[a, j]$ Xanthene Derivatives in Presence of Effective Synergetic Catalytic System Bleaching Earth Clay and PEG-600. Catalysts 2021, 11, 1294. https:// doi.org/10.3390/catal11111294

Academic Editor: Laura Antonella Aronica

Received: 16 August 2021

Accepted: 19 October 2021

Published: 27 October 202

Publisher's Note: MDPI stays neutral with regard to jurisdictional claims in published maps and institutional affiliations.

Copyright: (c) 2021 by the authors. Licensee MDPI, Basel, Switzerland. This article is an open access article distributed under the terms and conditions of the Creative Commons Attribution (CC BY) license (https:// creativecommons.org/licenses/by/ $4.0 /)$.
1 Department of Biochemistry, Dr. Babasaheb Ambedkar Marathwada University, Aurangabad 431004, Maharashtra, India

2 Department of Chemistry, Dr. Babasaheb Ambedkar Marathwada University, Aurangabad 431004, Maharashtra, India; giribalamb@gmail.com

3 Department of Botany, Dr. Babasaheb Ambedkar Marathwada University, Aurangabad 431004, Maharashtra, India; pvraithak@yahoo.com

4 Department of Chemistry, Government Institute of Science, Mumbai 400032, Maharashtra, India; vtkd@rediffmail.com

5 Scrips Pharma, Mallapur, Hyderabad 50076, Telangana, India; ravivarala@gmail.com

6 Department of Chemistry, College of Science, King Saud University, P.O. Box 2455, Riyadh 11451, Saudi Arabia; mkuniyil@ksu.edu.sa (M.K.); mhatshan@ksu.edu.sa (M.R.H.)

7 Department of Advanced Materials Engineering for Information \& Electronics, Kyung Hee University, 1732 Deogyeong-daero, Giheung-gu, Yongin-si 446-701, Gyeonggi-do, Korea; shaikbaji2@khu.ac.kr

8 Research Institute for the Creation of Functional and Structural Materials, Fukuoka University, 8-19-1 Nanakuma, Jonan-ku, Fukuoka 814-0180, Japan; altaf.mh7@gmail.com

* Correspondence: statkore0@gmail.com (S.T.A.); sfadil@ksu.edu.sa (S.F.A.)

\begin{abstract}
The synthesis of 14-aryl 14H-dibenzo[a,j]xanthenes is achieved by a simple condensation reaction between $\beta$-naphthol with aryl or alkyl aldehydes in an effective synergetic catalytic system created by combining basic bleaching earth clay and PEG-600. The advantages of the present method include catalyst recyclability, superior product yield, a shorter reaction time and the avoidance of hazardous reagents. Synthesized xanthene derivatives were also screened for their antibacterial activity against Staphylococcus aureus (MTCC 96) and Pseudomonas aeruginosa (Wild).
\end{abstract}

Keywords: xanthene; aldehydes; $\beta$-naphthol; bleaching earth clay; PEG-600

\section{Introduction}

There has been considerable interest in the development and synthesis of xanthene derivatives because of their wide range of biological and pharmaceutical applications. Xanthene's moiety exhibits a range of valuable properties that could be put to use in biological contexts, such as antiviral, antibacterial and anti-inflammatory properties [1]. Moreover, functionalized xanthenes, such as diversonol, globosuxanthone A and nidulalin A, are used as anticancer drugs (Figure 1).

It should be mentioned, too, that benzoxanthene derivatives have shown beneficial functions as sensitizers in photodynamic therapy (PDT), as well as in controlling localized tumors [2]. It is also noteworthy that the extended conjugation of this important group of oxygen heterocycles confers interesting spectroscopic properties which have many applications in laser technology [3] and dyes. These compounds can also be used as luminescent sensors [4]. There are many reports on the synthesis of xanthene derivatives, including aryne cycloaddition to phenols [5], intramolecular coupling of aldehydes and ketones [6], cyclodehydration [7], the reaction of $\beta$-naphthol with formamide [8], 
$\alpha$-naphthol-1-methanol [9] and carbon monoxide [10]. However, these reported methods have many disadvantages, such as harsh reaction conditions, low yields, prolonged reaction times and require the use of excessive quantities of reagents and toxic solvents. To overcome these limitations, the reaction has recently been improved by mixing $\beta$ naphthol with aldehydes in the presence of catalysts, such as natural acidic ionic liquid immobilized on magnetic silica [11], task specific dicationic acidic IL [12], MCM-41@Schiff Base-Mn(OAc) $)_{2}$ in water [13], Amberlyst-15 [14], LiBr [15], sulfamic acid [16], $p$-TSA [17], $\mathrm{I}_{2}$ [18], $\mathrm{Fe}\left(\mathrm{HSO}_{4}\right)_{3}$ [19], $\mathrm{BF}_{3} \cdot \mathrm{SiO}_{2}$ [20], oxalic acid [21], dipyridine cobalt chloride [22], wet cyanuric acid [23], silica-supported perchloric acid [24], $\mathrm{Al}\left(\mathrm{HSO}_{4}\right)_{2}$ [25], SelectfluorTM [26], hydrochloric acid or phosphoric acid [27], $\mathrm{H}_{2} \mathrm{SO}_{4}$ in acetic acid as solvent [28] and silica sulfuric acid [29]. These methods suffer from one or more disadvantages, such as drastic reaction conditions, long reaction times, a need for special apparatus and the use of hazardous solvents. Thus, the development of new alternative methods which avoid the use of toxic catalysts and hazardous solvents to construct xanthene derivatives is still desirable.<smiles>Cc1cc(O)c2c(c1)O[C@]1(C)[C@@H](O)CC[C@@H](O)[C@]1(O)C2=O</smiles>

Diversonol<smiles>COC(=O)[C@]1(C)c2c(oc3cccc(O)c3c2=O)C=C[C@H]1O</smiles>

Globosuxanthone A<smiles>COC(=O)[C@@]12Oc3cc(C)cc(O)c3C(=O)C1=CC=C[C@H]2O</smiles>

Nidulalin A

Figure 1. Biologically active molecules.

Due to stringent and increasing environmental regulations, the chemical industry needs to develop eco-compatible synthetic methodologies leading to a detailed reexamination of the most important synthetic processes [30]. Among the heterogeneous catalysts, naturally occurring clay has unique physical and chemical properties, such as selectivity, acidic/basic nature and thermal stability. Bleaching earth clay ( $\mathrm{pH} 12.5)$ is a highly efficient heterogeneous base catalyst that has been used for several base catalyzed organic reactions [31-33]. The small (5 micron) particle size of the clay renders a huge surface area compared with other solid-supported catalysts.

Recently, attention has been drawn to the development of environmentally benign solvents, such as ionic liquids [34], water [35] and polyethylene glycols [36]. The value of a new solvent medium primarily depends on its environmental impact, the ease with which it can be recycled, low vapor pressure, non-inflammability and high polarity for solubilization. Herein, we wish to report bleaching earth clay and PEG-600 as a new and efficient recyclable medium for the synthesis of 14-substitued-14-H-dibenzo[ $[a, j]$ xanthenes by reacting $\beta$-naphthol with aldehydes (Scheme 1 ).

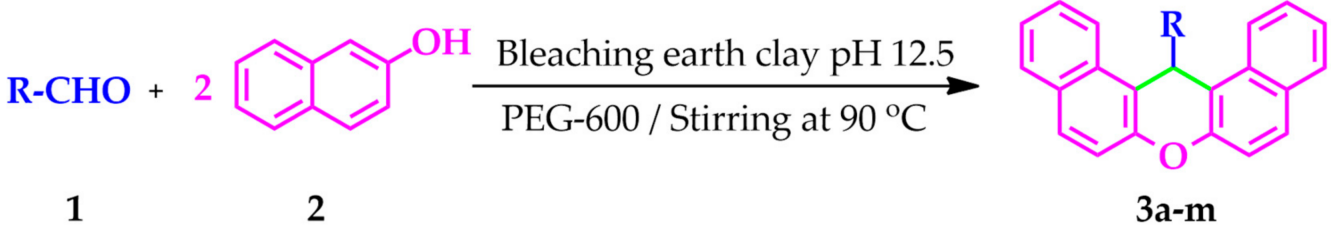

Scheme 1. General scheme for the synthesis of 14-substituted-14-H-dibenzo[ $a, j]$ xanthenes.

\section{Results and Discussion}

\subsection{Optimization of Reaction Conditions and Scope of the Reaction}

In a preliminary experiment, a model reaction between 4-chloro benzaldehyde ( $2 \mathrm{mmol})$ and $\beta$-naphthol $(4 \mathrm{mmol})$ to convert it into corresponding 14-(4-chlorophenyl)-14-Hdibenzo $[a, j]$ xanthenes derivative was studied. The effects of various reaction parameters, 
such as the effect of solvents/catalysts and temperature and reaction conditions, were evaluated to optimize the reaction (Table 1). The product was not formed under neat conditions at a high temperature (Table 1, Entry 1). Individual screening of some basic catalysts, such as triethylamine (TEA), piperidine, morpholine, and PEG-200, $-400,-600$ as solvents were studied for the same model reaction, but none of these catalysts and solvents gave a satisfactory yield (Table 1, Entries 2-4 and 6-8). We also performed the reaction using Bleaching earth clay as a heterogeneous catalyst to achieve a good yield (Table 1 , Entry 5). The effect of the bleaching earth clay catalyst along with PEG-200, -400 and -600 solvent system at room temperature and higher temperature was also studied (Table 1, Entries 9-12). The optimized results proved to be quite interesting, showing a pronounced increment in product yield (85-95\%) within a time of $45 \mathrm{~min}$. The overall findings of this experiment are that the combination of PEG-600 with bleaching earth clay catalyst at $90{ }^{\circ} \mathrm{C}$ gives the best results in terms of yield and time as shown in Table 1, Entry 12 (Scheme 2); the replacement of PEG-600 by universal solvent water with bleaching earth clay did not furnish the desired product in terms of high percentage yield (Table 1, Entry 13). Next, we tested polar protic solvents, such as methanol and ethanol, and conducted the reaction with polar aprotic solvents, such as acetonitrile and dichloromethane with bleaching earth catalyst at $90^{\circ} \mathrm{C}$, and found that these reactions resulted in lower product yields of low quality (Table 1, Entries 14-17).

In order to obtain the desired product yield, we have optimized the bleaching earth clay catalyst concentration in wt.\% for the same reaction (Table 2). Using 5 and $7 \mathrm{~mol} \%$ of catalyst gave lower yields of the product (Table 2, Entries 1-4), even after a prolonged reaction time. $10 \mathrm{~mol} \%$ of catalyst concentration was sufficient to obtain an excellent product yield, but use of $12 \mathrm{~mol} \%$ of catalyst was not able to increase the yield.

Therefore, $10 \mathrm{~mol} \%$ of basic bleaching earth clay catalyst in the presence of PEG-600 at $90{ }^{\circ} \mathrm{C}$ is sufficient to push the reaction in the forward direction, as shown in Table 2.<smiles>O=CC1=C[C+]=C(Cl)C=C[C+]1</smiles>

1

2

\section{$\underset{\text { PEG-600 / Stirring at } 90^{\circ} \mathrm{C}}{\stackrel{\text { Bleaching earth clay } \mathrm{pH} 12.5}{\longrightarrow}}$}

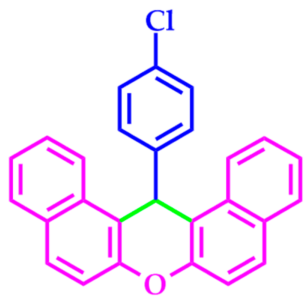

3a

Scheme 2. 14-(4-chlorophenyl)-14-H-dibenzo[a,j]xanthene (3a).

Table 1. Optimization of reaction conditions ${ }^{a}$.

\begin{tabular}{|c|c|c|c|c|}
\hline Entry & Solvent/Catalyst & Temp $\left({ }^{\circ} \mathrm{C}\right)$ & Time (min) & Yield (\%) b \\
\hline 1 & Neat & 90 & 300 & No reaction \\
\hline 2 & $\mathrm{Et}_{3} \mathrm{~N}$ & $\mathrm{RT} / 90$ & 300 & No reaction $/ 10$ \\
\hline 3 & Piperidine & $\mathrm{RT} / 90$ & 300 & No reaction/15 \\
\hline 4 & Morpholine & $\mathrm{RT} / 90$ & 300 & 15 \\
\hline 5 & Bleaching earth clay & $\mathrm{RT} / 90$ & 100 & 40 \\
\hline 6 & PEG-200 & 90 & 100 & 25 \\
\hline 7 & PEG-400 & 90 & 100 & 30 \\
\hline 8 & PEG-600 & 90 & 100 & 40 \\
\hline 9 & PEG-200/bleaching earth clay & 90 & 100 & 70 \\
\hline 10 & PEG-400/bleaching earth clay & 90 & 60 & 75 \\
\hline 11 & PEG-600/bleaching earth clay & RT & 45 & 70 \\
\hline 12 & PEG-600/bleaching earth clay & $50 / 70 / 90 / 100$ & 45 & $70 / 80 / 95 / 95$ \\
\hline 13 & Water/bleaching earth clay & 90 & 45 & 20 \\
\hline 14 & DCM/bleaching earth clay & 90 & 45 & 30 \\
\hline 15 & $\mathrm{Me} 0 \mathrm{H} /$ bleaching earth clay & 90 & 45 & 40 \\
\hline 16 & EtOH/bleaching earth clay & 90 & 45 & 40 \\
\hline 17 & Acetonitrile/bleaching earth clay & 90 & 45 & 40 \\
\hline
\end{tabular}

a 4-Chlorobenzaldehyde (2 mmol), (3-naphthol (4 mmol), bleaching earth clay and PEG-600 ${ }^{\mathrm{b}}$ Isolated yields. 
The tolerance of various aldehydes with functional groups, $\mathrm{NO}_{2}, \mathrm{OMe}, \mathrm{NMe}_{2}, \mathrm{Cl}$ and F, under the standard optimized reaction conditions was examined (Table 3, Entries 1-12), as well as aliphatic aldehyde (Entry 13). Moreover, the reactions were clean, with excellent yields without side product formation.

Table 2. Catalytic study of bleaching earth clay in the presence of PEG-600.

\begin{tabular}{ccccc}
\hline Entry & $\begin{array}{c}\text { Catalyst } \\
(\mathbf{w t .} \%)\end{array}$ & $\begin{array}{c}\text { Temp } \\
\left({ }^{\circ} \mathbf{C}\right)\end{array}$ & $\begin{array}{c}\text { Time } \\
(\mathbf{m i n})\end{array}$ & $\begin{array}{c}\text { Yield } \\
(\%)\end{array}$ \\
\hline 1 & 5 & RT & 100 & 40 \\
2 & 5 & 80 & 100 & 60 \\
3 & 5 & 90 & 80 & 70 \\
4 & 7 & 90 & 80 & 70 \\
5 & 10 & 80 & 60 & 90 \\
6 & 10 & 90 & 45 & 95 \\
7 & 12 & 90 & 45 & 95 \\
\hline
\end{tabular}

Table 3. Synthesis of 14-substituted-14-H-dibenzo[ $a, j]$ xanthenes.

\begin{tabular}{|c|c|c|c|c|c|}
\hline Entry & Aldehyde & Product & & Time (min) & Yield (\%) \\
\hline 1 & & & $3 a$ & 45 & 95 \\
\hline 2 & & & $3 b$ & 50 & 96 \\
\hline 3 & & & $3 c$ & 50 & 94 \\
\hline 4 & & & $3 d$ & 50 & 95 \\
\hline
\end{tabular}


Catalysts 2021, 11, 1294

5 of 14

Table 3. Cont.<smiles>O=Cc1ccc(Cl)cc1Cl</smiles>

6<smiles>O=Cc1ccccc1</smiles><smiles>c1ccc(C2c3c(ccc4ccccc34)Oc3ccc4ccccc4c32)cc1</smiles>

$3 e$

40

96

7<smiles>Brc1ccc(C2c3c(ccc4ccccc34)Oc3ccc4ccccc4c32)cc1</smiles>

$3 f$

43

95

8<smiles>O=Cc1ccc(Br)cc1</smiles>

$3 g$

50

96

9<smiles>COc1ccc(C=O)cc1</smiles><smiles>COc1ccc(C2c3c(ccc4ccccc34)Oc3ccc4ccccc4c32)cc1</smiles>

$3 h$

65

90<smiles>Cc1ccc(C=O)cc1</smiles><smiles>Cc1ccc(C2c3c(ccc4ccccc34)Oc3ccc4ccccc4c32)cc1</smiles>

$3 \mathbf{i}$

60

91

10<smiles>CNc1ccc(C=O)cc1</smiles><smiles>CN(C)c1ccc(C2c3c(ccc4ccccc34)Oc3ccc4ccccc4c32)cc1</smiles>

jj

70

89 
Table 3. Cont.

Entry Aldehyde

The principles of green chemistry tell us that organic reactions are superior if they produce a good product yield within a short reaction time and using safer techniques. Along with these conditions, another important factor is the reusability of the catalyst, which gives us information about how much longer our catalyst is active for. Therefore, the possibility of recycling the catalyst was examined for the same model reaction.

After completion of the reaction, dry ether was added to the reaction mixture. The catalyst was filtered, washed, dried and then recycled for four times. It can be seen that in the first three runs, activity was more or less maintained, but after the third run it starts to decrease. This may be due to pore blockage in the bleaching earth clay. The results of recycling are summarized in the form of a bar chart (Figure 2).

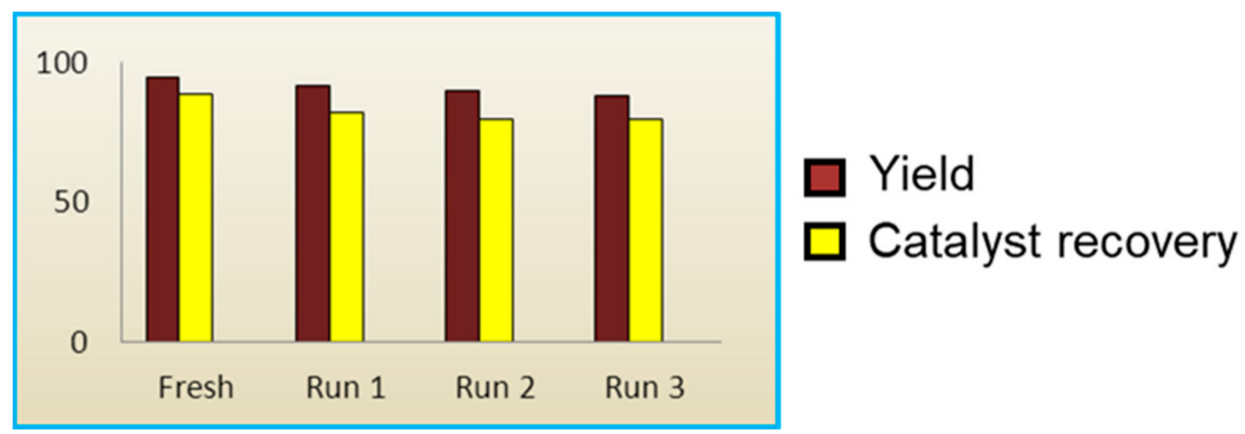

Figure 2. Reuse and recovery of bleaching earth clay and its effect on yield.

\subsection{Reaction Mechanism \\ 2.2.1. Structure of Clay}

Bleaching earth is a type of clay mineral. Composed of hydrated aluminosilicates, it always contains large amounts of crystalline silica. Silicates have a tetrahedral structure, while aluminates are octahedral and have a structure composed of separate layers like sheets of paper. Each clay sheet is slightly separate from those on either side, having 
negative charges on its surface and positive charge on edges. Negative charges are balanced by the positive charges present inside them in the form of cation (e.g., $\mathrm{Si}^{+2}, \mathrm{Al}^{+3}, \mathrm{Fe}^{+2}$, $\mathrm{Mg}^{+2}$ ). Each layer is separated internally by an interlayer space, as shown in Figure 3. These interlayers also contain adsorbed cation which is bonded to water molecules through weak Vander-waals forces. At low $\mathrm{pH}$ (acidic) environment these aluminosilicate layers are positively charged on their edges but become negatively charged in a high basic $\mathrm{pH}$ environment. Thus, at $\mathrm{pH} 12.5$ the surface and edges of clay become fully negatively charged. The origins of charge deficiency on aluminosilicate layers can be seen by following the reaction in Scheme 3.
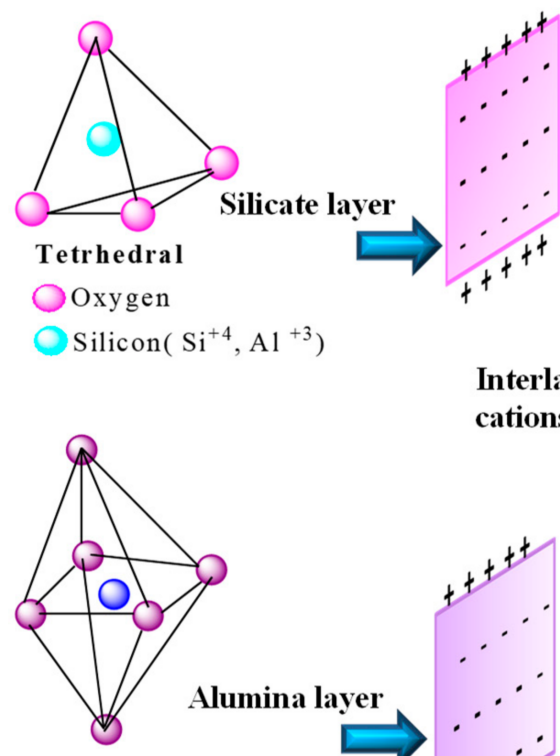

\section{Octahedral}

Oxygen-hydroxyl

Aluminium $\left(\mathrm{Al}^{+3}, \mathrm{Mg}^{+2}, \mathrm{Fe}^{+2}\right)$

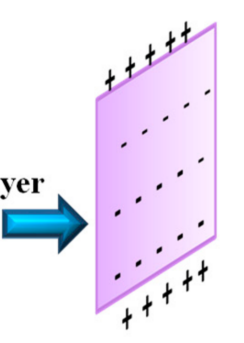

Interlayer containing cations

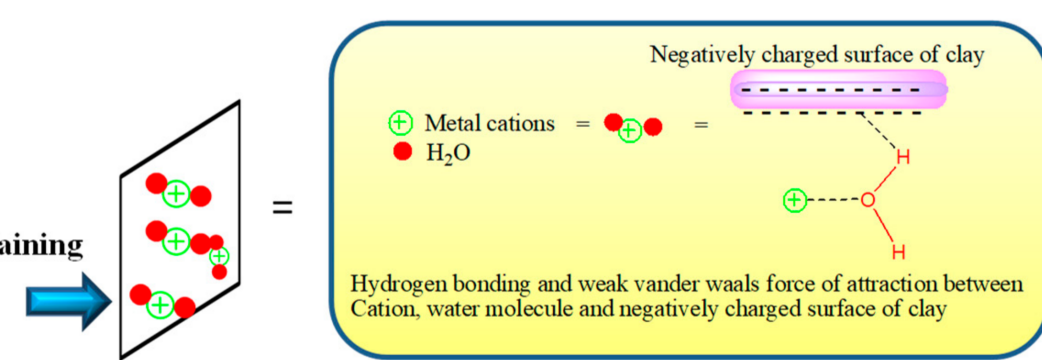

Figure 3. Structure of clay: Aluminosilicate layers with interlayers containing cations and water molecules.

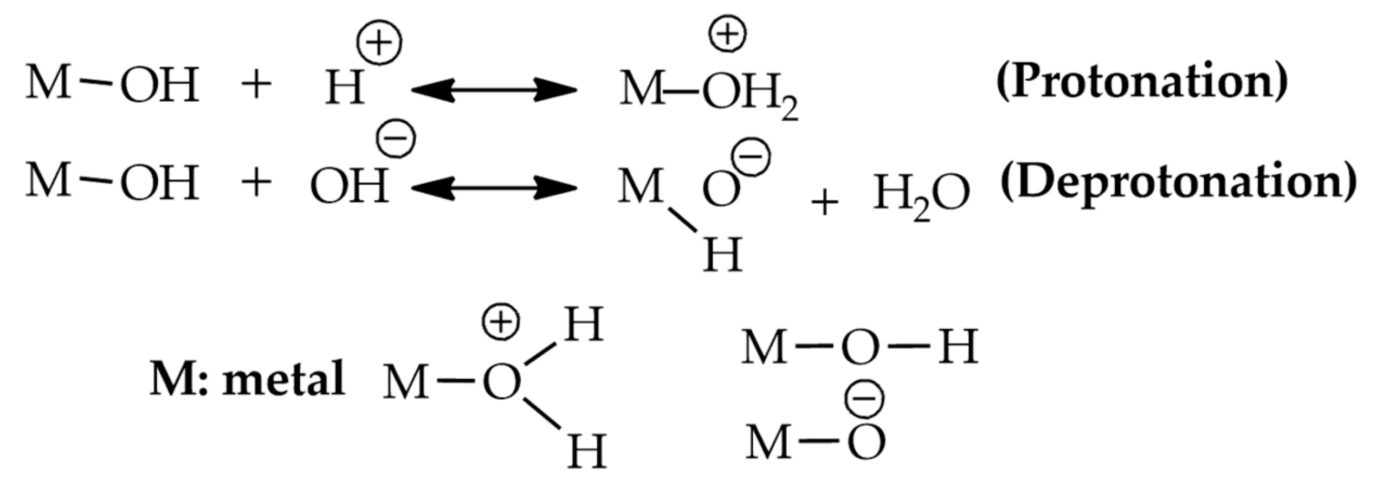

Scheme 3. pH dependent charges.

\subsubsection{Polyethylene Glycol}

PEG is made up of ethereal oxygen linkages and free hydroxyl groups. During the reaction PEG increases the electrophilicity of carbonyl carbon and the nucelophilicity of $\beta$-napthol through hydrogen bonding, as shown in Figure 4. PEG, along with the reactant, 
enters in the intercationic layer of clay where already most of the water molecules along with adsorbed cations are present at the negative surface of the clay. But when PEG enters inside the interlayer, water molecules are desorbed from the surface whereas PEG, along with the reactants, is adsorbed at the clay surface [37,38]. Afterwards, an increase in the concentration of PEG inside the interlayer results in an increase in the distance between intercalations, and finally the dispersion of clay with a large surface area takes place. As the surface area increases, more and more adsorption of PEG along with reactant molecules takes place, which results in good productivity. A possible detailed mechanism for the synthesis of xanthene derivatives is shown in Scheme 4.

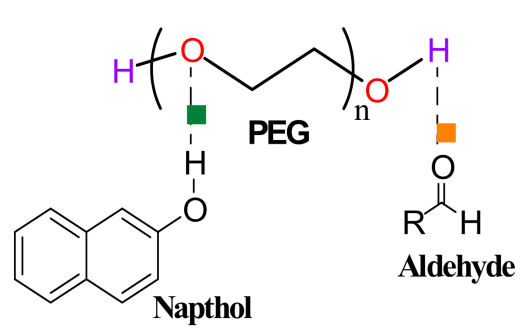

1. Interaction of PEG with reactants

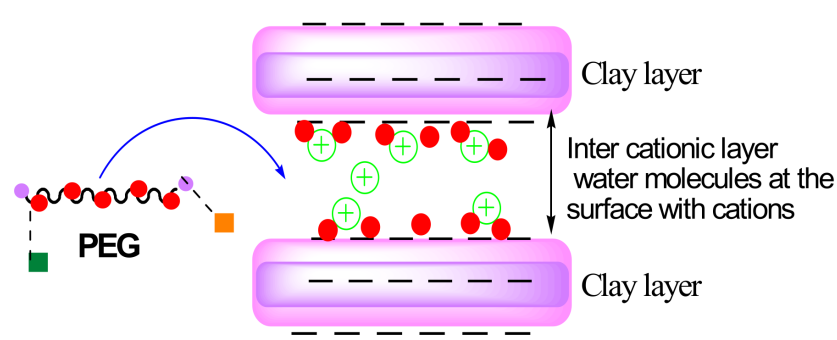

2. Entering PEG with reactants inside the interlayer of clay
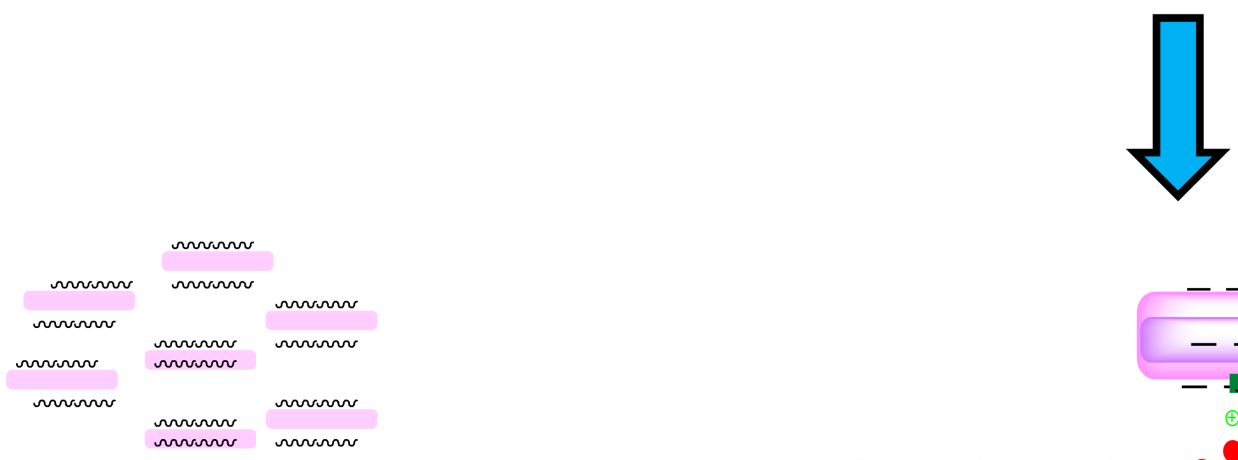

5. Increase in Clay dispersion with increased surface area
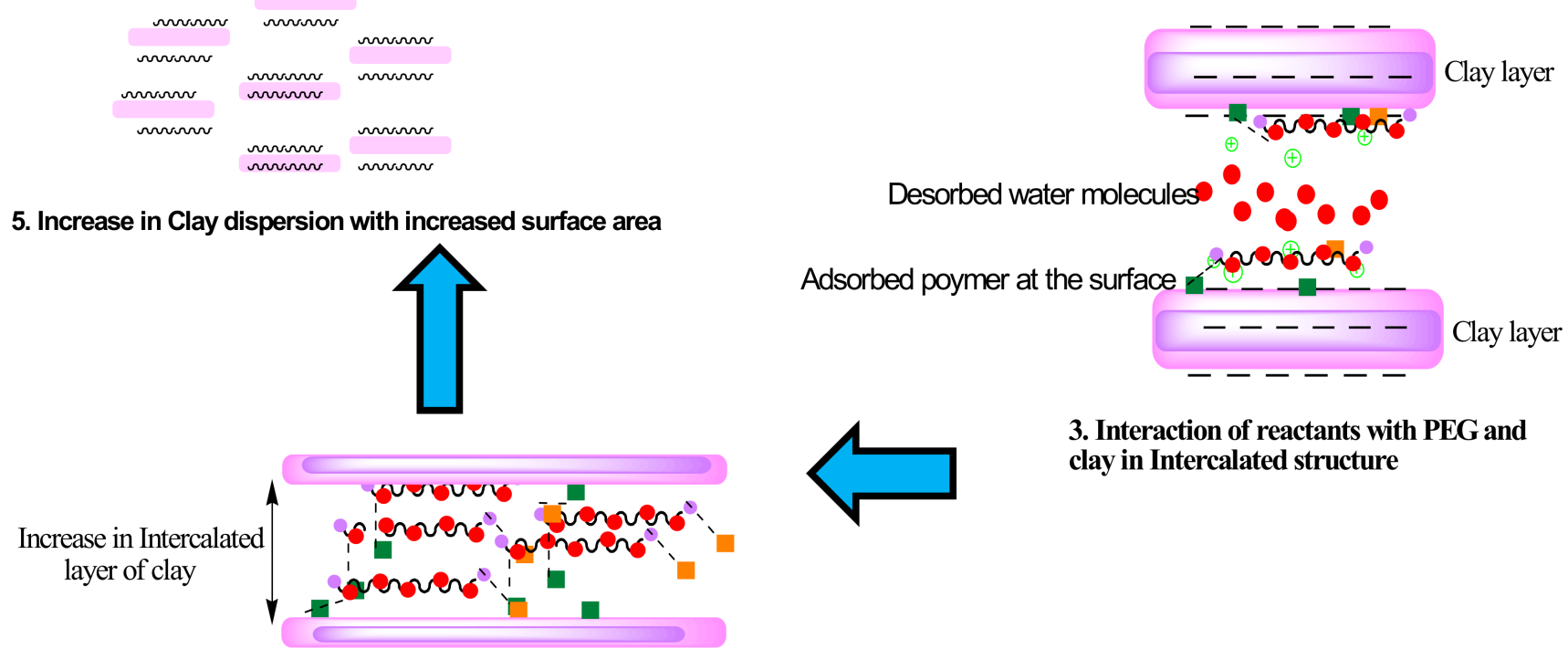

3. Interaction of reactants with PEG and clay in Intercalated structure

\section{Increase in intercalated layer due to PEG adsorption}

Figure 4. Graphical illustration of probable adsorption of PEG along with reactants on clay surface. 


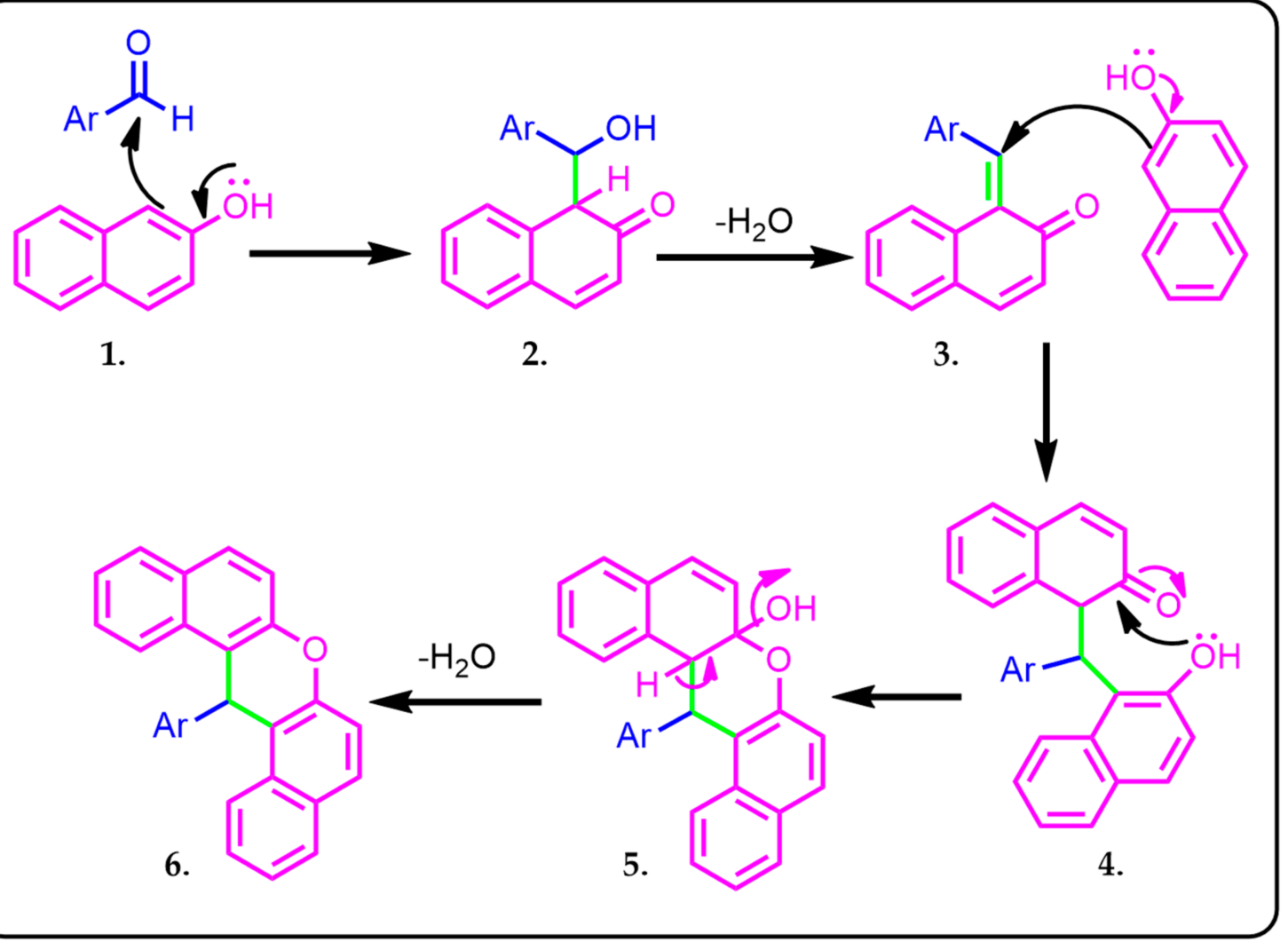

Scheme 4. Plausible reaction mechanism for the synthesis of xanthene derivatives.

\subsubsection{DFT Studies on the Mechanistic Details of the Regioselective Reactions}

Density functional theory (DFT) geometry optimization calculations were performed using the Gaussian 16, version A03 software [39]. The M06-2X functional and double zeta quality basis set $(6-31 G(d, p))$ has been used in the computations to obtain the reliable energetics and geometries for the models. The M06-2X method is a hybrid metafunctional method, widely used for non-covalent interactions and molecular energy predictions for main-group elements [40]. All the stationary points for the ground state and transition states were characterized by performing the frequency calculations and ensured that the frequencies must be zero and one, respectively. The transition states were further characterized by performing the intrinsic reaction coordinate calculations and the corresponding paths met the desired stationary points as shown in Scheme 4. All the reaction energies and transition state energies were calculated by subtracting the total energies of the complex structure from its constituent molecules.

Figure 5 shows the reaction energy profile for the two reactions, the electron drawing group ( $\mathbf{3} \mathbf{b})$ and the electron donating group ( $3 \mathbf{j})$, and the transformation to the corresponding xanthene derivatives. The energy transformation curve is similar for both reactions and these two reactions are exothermic in nature. However, the $\mathbf{3 b}$ pathway is energetically more feasible and thermodynamically preferred, which is also corroborated in the experimental synthesis and characterization. The transformation has mainly five activation energy barriers and two dehydration steps. The dehydration steps are the key steps in the transformation and are the rate determining steps (RDS). These two steps were observed in the transition states 2_3 and 5_6 with the activation energy barrier of ca. $60 \mathrm{kcal} / \mathrm{mol}$. Relatively, the 2_3 activation energy barrier for $3 \mathbf{b}$ is ca. $2.7 \mathrm{kcal} / \mathrm{mol}$ higher in energy than the 5_6 and evidently, RDS of the reaction. Moreover, In the formation of the C-O bond in step 4_5, $38.5 \mathrm{kcal} / \mathrm{mol}$ energy barrier was required, and it was ca. $20 \mathrm{kcal} / \mathrm{mol}$ lower than the RDS. In contrast, much lower energy was needed in the C-C bonds formation in 1_2 and 3_4 and these steps smoothly crossed to their corresponding products with 
ca. $20.6 \mathrm{kcal} / \mathrm{mol}$ and $24.2 \mathrm{kcal} / \mathrm{mol}$ activation energies respectively. Quantitatively, C-C bond formation steps show ca. $40 \mathrm{kcal} / \mathrm{mol}$ lower energy barrier than the RDS step of the reactions. Thermodynamically, $\mathbf{3 b}$ is $6 \mathrm{kcal} / \mathrm{mol}$ more stable than the $\mathbf{3 j}$ and hence highly selective in the regioselective transformation.

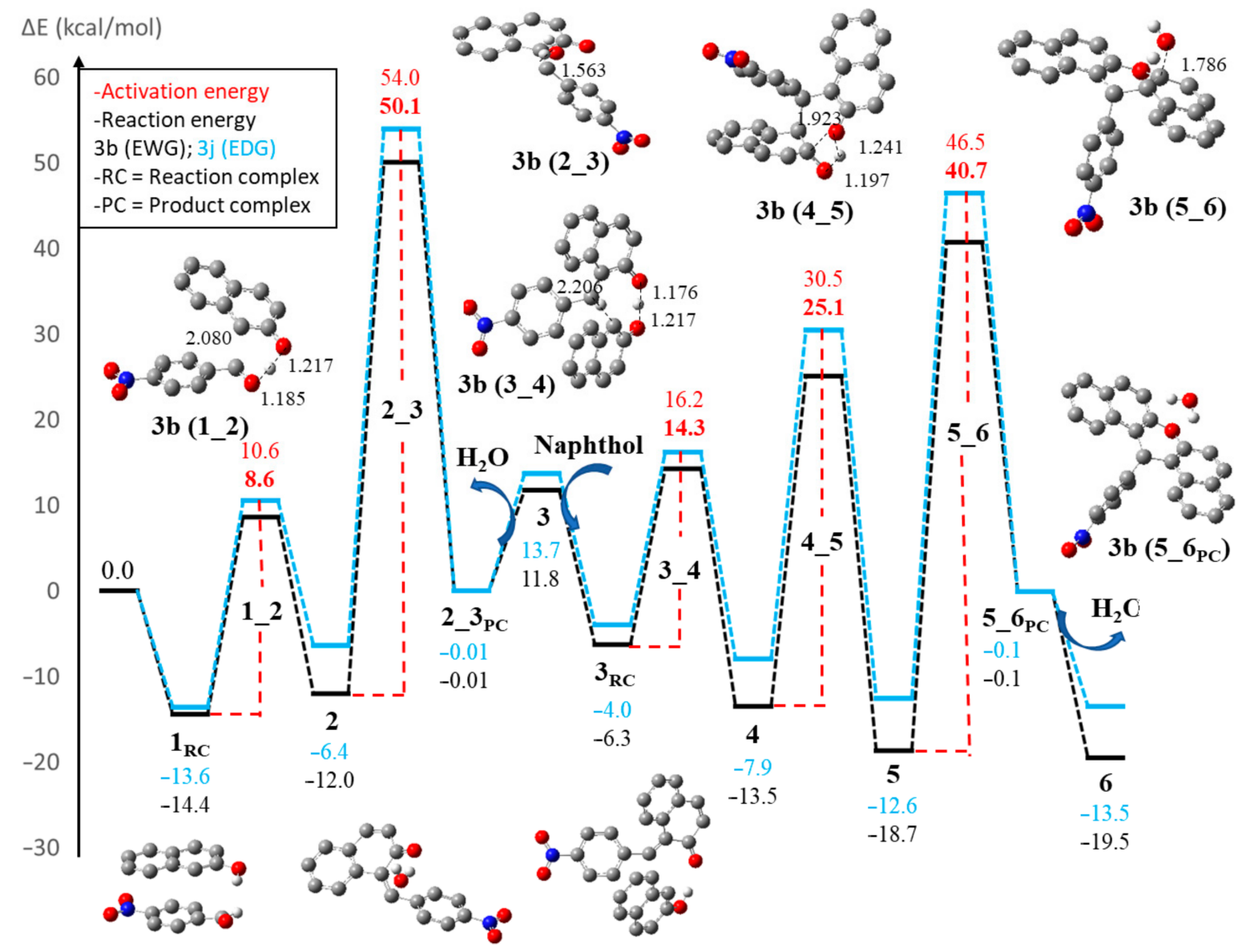

Figure 5. Reaction energy profile for the xanthene derivative formation using the M06-2X/6-31G(d,p) level of theory. The activation energy (red) for $\mathbf{3 b}$ is shown in bold and for $\mathbf{3 e}$ in light.

\section{Experimental}

All reagents and solvents were of reagent grade quality and were obtained from commercial suppliers. All solvents were dried by refluxing with appropriate drying agents and were distilled before use. Follow-up of the reactions and the purity of the compounds was performed and tested in each step by TLC $\left(\mathrm{SiO}_{2}\right)$ using a DC AlufolienKiesel gel $60 \mathrm{~F}$ 254 Merck (Darmstadt, Germany). Compounds were visualized by Camag TLC devices (Berlin, Germany). IR spectra were recorded on a Bruker spectrophotometer (Berlin, Germany) using $\mathrm{KBr}$ disks and the absorption bands are expressed in $\mathrm{cm}^{-1} \cdot{ }^{1} \mathrm{H} \mathrm{NMR}$ and ${ }^{13} \mathrm{C}$ NMR spectra were recorded on a Varian as 400 and $300 \mathrm{MHz}$ spectrometer (Palo Alto, CA, USA) in $\mathrm{CDCl}_{3}$, chemical shifts (d) are in ppm relative to TMS and coupling constants $(J)$ are expressed in Hertz $(\mathrm{Hz})$. Mass spectra were taken on a Macro mass spectrometer (Waters, MA, USA) by electro-spray method (ES).

\subsection{Typical Procedure for the Synthesis of 14-(4-Chlorophenyl)-14H-Dibenzo[a,j]Xanthene (3a)}

To a mixture of $p$-chloro benzaldehyde $(2 \mathrm{mmol})$ and -naphthol $(4 \mathrm{mmol})$, PEG-600 solvent $(4 \mathrm{~mL})$ and bleaching earth clay catalyst of $\mathrm{pH} 12.5(10 \mathrm{~mol} \%)$ was placed in a $10 \mathrm{~mL}$ round-bottomed flask. The mixture was stirred for $5 \mathrm{~min}$ at room temperature and then temperature raised to $90^{\circ} \mathrm{C}$ for the stipulated time period (Table 3). After completion of the reaction (TLC), the reaction mixture was cooled to room temperature and the product 
was taken into dry ether $(25 \mathrm{~mL})$ and the catalyst was filtered and washed with chloroform for reuse. The organic layer was washed successively with water $(10 \mathrm{~mL})$, sat. $\mathrm{NaHCO}_{3}$ $(5 \mathrm{~mL})$, and then dried over anhydrous sodium sulfate to get the crude product. It was then recrystallized from hot aqueous ethanol to get the pure product. The recovered bleaching earth can be reused for a number of cycles without any significant loss of activity.

\subsection{Spectral Data of Representative Compounds}

3.2.1. 14-(4-Chlorophenyl)-14H-Dibenzo[ $[a, j]$ Xanthene (3a)

Yellow solid; $\mathrm{mp} 283-287^{\circ} \mathrm{C}$; IR (KBr): $v_{\max } \mathrm{cm}^{-1} 857,1245,1388,1496,1581,1621$, 3036; ${ }^{1} \mathrm{H}$ NMR $\left(\mathrm{CDCl}_{3}, 400 \mathrm{MHz}\right) \delta: 6.47(\mathrm{~s}, 1 \mathrm{H}), 7.12(\mathrm{~d}, 2 \mathrm{H}, J=8.5 \mathrm{~Hz}), 7.48-7.39(\mathrm{~m}, 4 \mathrm{H})$, $7.48(\mathrm{~d}, 2 \mathrm{H}, J=8.8 \mathrm{~Hz}), 7.63-7.56(\mathrm{~m}, 2 \mathrm{H}), 7.82(\mathrm{~d}, 2 \mathrm{H}, J=8.8 \mathrm{~Hz}), 7.86(\mathrm{~d}, 2 \mathrm{H}, J=8.0 \mathrm{~Hz})$, $8.34(\mathrm{~d}, 2 \mathrm{H}, J=8.5 \mathrm{~Hz}) ;{ }^{13} \mathrm{C}$ NMR $\left(75 \mathrm{MHz}, \mathrm{CDCl}_{3}, \mathrm{ppm}\right) \delta: 37.46,116,118,122.42,124.36$, 127, 128.65, 129.93, 129.07, 129.48, 131, 131.26, 132.18, 143.47, 148.8; Mass ( $m / z): 394\left[\mathrm{M}^{+} 1\right]$; Anal. calcd for $\mathrm{C}_{27} \mathrm{H}_{17} \mathrm{ClO}$ : C, 82.55; H, 4.35; Cl, 9.01; Found: C, 82.54; H, 4.39; Cl, 9.03.

\subsubsection{4-(4-Nitrophenyl)-14H-Dibenzo[ $[a, j]$ Xanthene (3b)}

Yellow solid; mp 306-308 ${ }^{\circ} \mathrm{C}$; IR (KBr): $v_{\max } \mathrm{cm}^{-1} 805,817,1245,1594,1631,3068 ;{ }^{1} \mathrm{H}$ $\operatorname{NMR}\left(\mathrm{CDCl}_{3}, 400 \mathrm{MHz}\right) \delta: 6.62(\mathrm{~s}, 1 \mathrm{H}, \mathrm{C}-\mathrm{H}), 7.44\left(\mathrm{ddd}, 2 \mathrm{H}, J_{1}=8.1, J_{2}=6.8\right.$ and $J_{3}=$ $1.0 \mathrm{~Hz}), 7.53(\mathrm{~d}, 2 \mathrm{H}, J=8.8 \mathrm{~Hz}), 7.62\left(\mathrm{ddd}, 2 \mathrm{H}, J_{1}=8.3, J_{2}=6.8\right.$ and $\left.J_{3}=1.4 \mathrm{~Hz}\right), 7.68(\mathrm{~d}$, $2 \mathrm{H}, J=8.8 \mathrm{~Hz}), 7.83-7.90(\mathrm{~m}, 4 \mathrm{H}), 8.0(\mathrm{~d}, 2 \mathrm{H}, J=8.8 \mathrm{~Hz}), 8.29(\mathrm{~d}, 2 \mathrm{H}, J=8.3 \mathrm{~Hz}) ;{ }^{13} \mathrm{C} \mathrm{NMR}$ (75 MHz, $\left.\mathrm{CDCl}_{3}, \mathrm{ppm}\right) \delta: 152.1,148.7,146.2,131.1,129.6,129.2,128.9,127.2,124.6,123.9$, 122.0, 118.1, 115.7, 37.9; Mass (m/z): 403[M $\left.\mathrm{M}^{+} 1\right]$; Anal. calcd for $\mathrm{C}_{27} \mathrm{H}_{17} \mathrm{NO}_{3}$ : C, 80.37; $\mathrm{H}, 4.26$; N, 3.26; Found: C, 80.35; H, 4.27; N, 3.29 .

\subsubsection{4-(3-Nitrophenyl)-14H-Dibenzo[ $[a, j]$ Xanthene(3c)}

Yellow solid; $\mathrm{mp} 211-214{ }^{\circ} \mathrm{C}$; IR (KBr): $v_{\max } \mathrm{cm}^{-1} 803,815,1245,1583,1630,3053 ;{ }^{1} \mathrm{H}$ NMR $\left(\mathrm{CDCl}_{3}, 400 \mathrm{MHz}\right) \delta: 6.56$ (s, 1H, C-H), 7.10-8.72 (m, 16H, Ar-H); ${ }^{13} \mathrm{C}$ NMR $(75 \mathrm{MHz}$, $\left.\mathrm{CDCl}_{3}, \mathrm{ppm}\right) \delta: 32.9,118.0,118.5,123.0,124.6,125.0,125.4,127.8,128.1,129.4,129.6$, 129.9, 130.8, 132.1, 132.6, 134.5, 141.4, 147.5, 149.8; Mass (m/z): 403[ $\left.\mathrm{M}^{+} 1\right]$; Anal. calcd for $\mathrm{C}_{27} \mathrm{H}_{17} \mathrm{NO}_{3}$ : C, 80.37; H, 4.26; N, 3.26; Found: C, 80.39; H, 4.28; N, 3.23 .

\subsubsection{4-(3-Flurophenyl)-14H-Dibenzo[ $[a, j]$ Xanthene (3d)}

Faint yellow solid; $\mathrm{mp} 222-219^{\circ} \mathrm{C}$; IR (KBr): $v_{\max } \mathrm{cm}^{-1} 754,810,1247,1593,1602,3058$; ${ }^{1} \mathrm{H}$ NMR $\left(\mathrm{CDCl}_{3}, 400 \mathrm{MHz}\right) \delta: 6.81(\mathrm{~s}, 1 \mathrm{H}, \mathrm{C}-\mathrm{H}), 7.16-8.18(\mathrm{~m}, 16 \mathrm{H}, \mathrm{Ar}-\mathrm{H}) ;{ }^{13} \mathrm{C}$ NMR (75 MHz, $\mathrm{CDCl}_{3}$, ppm) $\delta: 162.8,148.7,147.5,147.3,131.3,131.1,129.8,129.7,129.3,128.8$, $126.9,124.4,123.8,122.4,118.1,116.6,115.4,115.3,113.6,113.4,37.8$; Mass $(m / z): 376\left[\mathrm{M}^{+} 1\right]$; Anal. calcd for $\mathrm{C}_{27} \mathrm{H}_{17} \mathrm{FO}$ : C, 86.15; H, 4.55; F, 5.05; Found: C, 86.15; H, 4.55; F, 5.06.

\subsubsection{4-(2,4-Dichlorophenyl)-14H-Dibenzo[ $a, j]$ Xanthene (3e)}

White solid; mp 241-244 ${ }^{\circ} \mathrm{C}$; IR (KBr): $v_{\max } \mathrm{cm}^{-1} 809,835,1249,1596,1635,3071,{ }^{1} \mathrm{H}$ $\operatorname{NMR}\left(\mathrm{CDCl}_{3}, 300 \mathrm{MHz}\right) \delta: 6.76(\mathrm{~s}, 1 \mathrm{H}, \mathrm{C}-\mathrm{H}), 6.92(\mathrm{~d}, 1 \mathrm{H}, J=8.7 \mathrm{~Hz}$ Ar-H), 7.25-7.77 (m, $12 \mathrm{H}, \mathrm{Ar}-\mathrm{H}), 8.46(\mathrm{~d}, 2 \mathrm{H}, J=8.4 \mathrm{~Hz}, \mathrm{Ar}-\mathrm{H}) ;{ }^{13} \mathrm{C} \mathrm{NMR}\left(75 \mathrm{MHz}, \mathrm{CDCl}_{3}, \mathrm{ppm}\right) \delta: 36.5,117.4$,

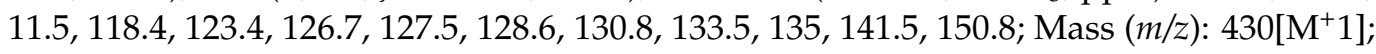
Anal. calcd for $\mathrm{C}_{27} \mathrm{H}_{16} \mathrm{Cl}_{2} \mathrm{O}: \mathrm{C}, 75.91 ; \mathrm{H}, 3.77 ; \mathrm{Cl}, 16.59$; Found: $\mathrm{C}, 75.90 ; \mathrm{H}, 3.78 ; \mathrm{Cl}, 16.57$.

\subsubsection{4-Phenyl-14H-Dibenzo $[a, j]$ Xanthene (3f)}

Brown solid; $\mathrm{mp} 180-182{ }^{\circ} \mathrm{C}$; IR (KBr): $v_{\max } \mathrm{cm}^{-1} 798,810,1241,1582,1619,3032 ;{ }^{1} \mathrm{H}$ $\operatorname{NMR}\left(\mathrm{CDCl}_{3}, 400 \mathrm{MHz}\right) \delta: 6.53(\mathrm{~s}, 1 \mathrm{H}, \mathrm{C}-\mathrm{H}), 7.02-8.13(\mathrm{~m}, 16 \mathrm{H}, \mathrm{Ar}-\mathrm{H}) ;{ }^{13} \mathrm{C}$ NMR $(75 \mathrm{MHz}$, $\left.\mathrm{CDCl}_{3}, \mathrm{ppm}\right) \delta: 44.7,117.4,118.8,123,127,129,129.3,133.6,145,153.7$; Mass $(\mathrm{m} / \mathrm{z}): 358\left[\mathrm{M}^{+} 1\right]$; Anal. calcd for $\mathrm{C}_{27} \mathrm{H}_{18} \mathrm{O}: \mathrm{C}, 90.47 ; \mathrm{H}, 5.06$; Found: C, 90.44; H, 5.10.

\subsubsection{4-(4-Bromophenyl)-14H-Dibenzo[ $[a, j]$ Xanthene (3g)}

Pink solid; $\mathrm{mp} 297-303{ }^{\circ} \mathrm{C}$; IR (KBr): $v_{\max } \mathrm{cm}^{-1} 515,604,705,740,806,962,1010$, 1238, 1402, 1514, 1592, 3063; ${ }^{1} \mathrm{H}$ NMR $\left(\mathrm{CDCl}_{3}, 400 \mathrm{MHz}\right) \delta: 6.45$ (s, 1H), 7.30-7.23 (m, 
2H), 7.45-7.38 (m, 4H), $7.50(\mathrm{~d}, 2 \mathrm{H}, J=8.8 \mathrm{~Hz}), 7.61\left(\mathrm{t}, 2 \mathrm{H}, J_{1}=\mathrm{J}_{2}=7.5 \mathrm{~Hz}\right), 7.82(\mathrm{~d}, 2 \mathrm{H}$, $J=8.8 \mathrm{~Hz}), 7.85(\mathrm{~d}, 2 \mathrm{H}, J=8.0 \mathrm{~Hz}), 8.33(\mathrm{~d}, 2 \mathrm{H}, J=8.5 \mathrm{~Hz}) ;{ }^{13} \mathrm{C} \mathrm{NMR}\left(75 \mathrm{MHz}, \mathrm{CDCl}_{3}\right.$, ppm) $\delta: 37.6,116.8,118.1,120.4,122.5,124.5,127.2,129.1,129.3,129.10,131.2,131.4,131.7$, 144.2, 148.8; Mass (m/z): 438[ $\mathrm{M}^{+} 1$ ]; Anal. calcd for $\mathrm{C}_{27} \mathrm{H}_{17} \mathrm{BrO}$ : C, 81.55; $\mathrm{H}, 5.35 ; \mathrm{Br}, 9.02$; Found: $\mathrm{C}, 82.04 ; \mathrm{H}, 5.59 ; \mathrm{Br}, 9.04$.

\subsubsection{4-(4-Methoxyphenyl)-14H-Dibenzo[ $[a, j]$ Xanthene (3h)}

White solid; mp 202-203 ${ }^{\circ} \mathrm{C}$; IR (KBr): $v_{\max } \mathrm{cm}^{-1} 736,815,1257,1588,1623,3039 ;{ }^{1} \mathrm{H}$ $\mathrm{NMR}\left(\mathrm{CDCl}_{3}, 400 \mathrm{MHz}\right) \delta: 3.59$ (s, 3H, OCH$\left.)_{3}\right), 6.40(\mathrm{~s}, 1 \mathrm{H}, \mathrm{C}-\mathrm{H}), 6.62(\mathrm{~d}, 2 \mathrm{H}, J=8.4 \mathrm{~Hz}$, Ar-H), 7.34-7.76 (m, 12H, Ar-H), 8.33 (d, 2H, J = 8.4 Hz, Ar-H); ${ }^{13} \mathrm{C} \mathrm{NMR}\left(75 \mathrm{MHz}, \mathrm{CDCl}_{3}\right.$, ppm) $\delta:$ 37, 54.2, 114, 117.2, 118.3, 123.5, 124.1, 127.4, 129.1, 129.4, 131.4, 133.7, 137.2, 149.3, 158.2; Mass (m/z): 388[M+1 1 ; Anal. calcd for $\mathrm{C}_{28} \mathrm{H}_{20} \mathrm{O}_{2}: \mathrm{C}, 86.57$; H, 5.18; Found: C, 86.54; $\mathrm{H}, 5.20$.

\subsubsection{4-(4-Methylphenyl)-14H-Dibenzo[a,j]Xanthene (3i)}

Brown red solid; $\operatorname{mp} 226-228^{\circ} \mathrm{C}$; IR (KBr): $v_{\max } \mathrm{cm}^{-1} 735,818,1240,1621,2835,2913$, 3041; ${ }^{1} \mathrm{H}$ NMR $\left(\mathrm{CDCl}_{3}, 400 \mathrm{MHz}\right) \delta: 2.13\left(\mathrm{~s}, 3 \mathrm{H}, \mathrm{CH}_{3}\right), 6.48(\mathrm{~s}, 1 \mathrm{H}), 6.97(\mathrm{~d}, 2 \mathrm{H}, \mathrm{J}=8.0 \mathrm{~Hz})$, 7.45-7.38 (m, 4H), $7.48(\mathrm{~d}, 2 \mathrm{H}, J=8.8 \mathrm{~Hz}), 7.62-7.55(\mathrm{~m}, 2 \mathrm{H}), 7.79(\mathrm{~d}, 2 \mathrm{H}, J=8.8 \mathrm{~Hz}), 7.84$ $(\mathrm{d}, 2 \mathrm{H}, J=8.0 \mathrm{~Hz}), 8.41(\mathrm{~d}, 2 \mathrm{H}, J=8.6 \mathrm{~Hz}) ;{ }^{13} \mathrm{C} \mathrm{NMR}\left(75 \mathrm{MHz}, \mathrm{CDCl}_{3}, \mathrm{ppm}\right) \delta: 20.5,36$, 117.3, 117.5, 117.5, 122.4, 124.5, 126.7, 127.8, 128.5, 131.6, 132, 135.5, 142.9, 148.9; Mass (m/z): 372[ $\left.\mathrm{M}^{+} 1\right]$; Anal. calcd for $\mathrm{C}_{28} \mathrm{H}_{20} \mathrm{O}$ : C, 90.29; $\mathrm{H}, 5.41$; Found: C, 90.32; $\mathrm{H}, 5.45$.

\subsubsection{4-(4-Dimethylamino-phenyl)-14H-Dibenzo[a,j]Xanthene (3j)}

Faint yellow solid; $\mathrm{mp} 197-199{ }^{\circ} \mathrm{C}$; IR (KBr): $v_{\max } \mathrm{cm}^{-1} 741,823,1260,1590,1626,3042$; ${ }^{1} \mathrm{H}$ NMR $\left(\mathrm{CDCl}_{3}, 400 \mathrm{MHz}\right) \delta: 4.58\left(\mathrm{~s}, 6 \mathrm{H}, \mathrm{NCH}_{3}\right), 7.22(\mathrm{~s}, 1 \mathrm{H}, \mathrm{C}-\mathrm{H}), 7.31(\mathrm{~d}, 2 \mathrm{H}, \mathrm{J}=8.7 \mathrm{~Hz}$, Ar-H), 7.43-7.46 (m, 2H, Ar-H), $7.62(\mathrm{t}, 4 \mathrm{H}, J=7.2 \mathrm{~Hz}, \mathrm{Ar}-\mathrm{H}), 7.75(\mathrm{~d}, 4 \mathrm{H}, J=9.1 \mathrm{~Hz}, \mathrm{Ar}-\mathrm{H})$, $7.84(\mathrm{~d}, 2 \mathrm{H}, J=8.1 \mathrm{~Hz}, \mathrm{Ar}-\mathrm{H}) ; 8.01(\mathrm{~d}, 2 \mathrm{H}, J=8.1 \mathrm{~Hz}, \mathrm{Ar}-\mathrm{H})$; Mass $(m / z)$ : 401[M $\left.{ }^{+} 1\right]$; Anal. calcd for $\mathrm{C}_{29} \mathrm{H}_{23} \mathrm{NO}$ : C, 86.79; $\mathrm{H}, 5.78 ; \mathrm{N}, 3.48$; Found: $\mathrm{C}, 86.76 ; \mathrm{H}, 5.80 ; \mathrm{N}, 3.51$.

\subsubsection{4-(4-Methylsulfanylphenyl)-14H-Dibenzo[ $a, j]$ Xanthene (3k)}

Grey solid; $\operatorname{mp} 211-218{ }^{\circ} \mathrm{C}$; IR (KBr): $v_{\max } \mathrm{cm}^{-1} 519,609,743,805,965,1085,1251$, 1404, 1430, 1592, 2980, 3071; ${ }^{1} \mathrm{H} \mathrm{NMR}\left(\mathrm{CDCl}_{3}, 400 \mathrm{MHz}\right) \delta: 2.30$ (s, 3H), 6.45 (s, 1H), 7.07-7.01 $(\mathrm{m}, 2 \mathrm{H}), 7.45-7.40(\mathrm{~m}, 4 \mathrm{H}), 7.48(\mathrm{~d}, 2 \mathrm{H}, \mathrm{J}=8.7 \mathrm{~Hz}), 7.59\left(\mathrm{ddd}, 2 \mathrm{H}, J_{1}=8.1 \mathrm{~Hz}, \mathrm{~J}_{2}=6.7 \mathrm{~Hz}\right.$ and $\left.J_{3}=1.1 \mathrm{~Hz}\right), 7.79(\mathrm{~d}, 2 \mathrm{H}, J=8.8 \mathrm{~Hz}), 7.84(\mathrm{~d}, 2 \mathrm{H}, J=8.1 \mathrm{~Hz}), 8.40(\mathrm{~d}, 2 \mathrm{H}, J=8.6 \mathrm{~Hz}) ;{ }^{13} \mathrm{C}$ $\mathrm{NMR}\left(75 \mathrm{MHz}, \mathrm{CDCl}_{3}\right.$, ppm) $\delta: 15.6,37.4,117.2,118.0,122.5,124.2,126.6,126.8,128.5,128.8$, $128.9,131.0,131.4,136.2,142.0,148.6$; Mass $(\mathrm{m} / \mathrm{z})$ : $404\left[\mathrm{M}^{+} 1\right]$; Anal. calcd for $\mathrm{C}_{28} \mathrm{H}_{20} \mathrm{OS}$ : C, 83.21; H, 4.97; Found: C, 83.17; H, 4.98.

\subsubsection{4-(4-t-Butylphenyl)-14H-Dibenzo[a,j]Xanthene (31)}

White solid; $\operatorname{mp} 299-305{ }^{\circ} \mathrm{C}$; IR (KBr): $v_{\max } \mathrm{cm}^{-1} 504,611,741,799,825,960,1239$, 1396, 1514, 1591, 2860, 2944, 3052; ${ }^{1} \mathrm{H}$ NMR $\left(\mathrm{CDCl}_{3}, 400 \mathrm{MHz}\right) \delta: 1.12$ (s, 9H), 6.46 (s, 1H), $7.14(\mathrm{~d}, 2 \mathrm{H}, J=8.2 \mathrm{~Hz}), 7.45-7.40(\mathrm{~m}, 4 \mathrm{H}), 7.49(\mathrm{~d}, 2 \mathrm{H}, J=8.6 \mathrm{~Hz}), 7.59\left(\mathrm{ddd}, 2 \mathrm{H}, J_{1}=8.2 \mathrm{~Hz}\right.$, $J_{2}=6.7 \mathrm{~Hz}$ and $\left.J_{3}=1.2 \mathrm{~Hz}\right), 7.78(\mathrm{~d}, 2 \mathrm{H}, J=8.7 \mathrm{~Hz}), 7.85(\mathrm{~d}, 2 \mathrm{H}, J=8.2 \mathrm{~Hz}), 8.41(\mathrm{~d}, 2 \mathrm{H}$, $J=8.5 \mathrm{~Hz}) ;{ }^{13} \mathrm{C}$ NMR $\left(75 \mathrm{MHz}, \mathrm{CDCl}_{3}, \mathrm{ppm}\right) \delta: 31.234 .2,37.4,117.4,118.0,122.6,124.2$, 126.5, 127.8, 128.5, 128.7, 128.9, 131.0, 131.4, 142.1, 148.6; Mass (m/z): 414 [M+1]; Anal. calcd for $\mathrm{C}_{31} \mathrm{H}_{26} \mathrm{O}: \mathrm{C}, 90.09$; $\mathrm{H}, 5.33$; Found: C, 90.12; $\mathrm{H}, 6.45$.

\subsubsection{4-Ethyl-14H-Dibenzo[ $a, j]$ Xanthene (3m)}

Faint yellow solid; mp $113-114{ }^{\circ} \mathrm{C}$; IR (KBr): $v_{\max } \mathrm{cm}^{-1} 1225,1617,2904,3043 ;{ }^{1} \mathrm{H}$ NMR $\left(\mathrm{CDCl}_{3}, 400 \mathrm{MHz}\right) \delta: 0.97\left(\mathrm{t}, 3 \mathrm{H}, J=6.2, \mathrm{CH}_{3}\right), 2.61\left(\mathrm{~m}, 2 \mathrm{H},-\mathrm{CH}_{2}-\right), 5.13(\mathrm{t}, 1 \mathrm{H}$, $J=6.2 \mathrm{~Hz}, \mathrm{CH}), 7.43-7.45(\mathrm{~m}, 12 \mathrm{H}, \mathrm{Ar}-\mathrm{H})$. Mass $(\mathrm{m} / \mathrm{z}): 310\left[\mathrm{M}^{+} 1\right]$; Anal. calcd.for $\mathrm{C}_{23} \mathrm{H}_{18} \mathrm{O}$ : C, 87.79; H, 5.79; Found: C, 87.76; H, 5.82. 


\section{Conclusions}

We have described a novel and efficient method for the preparation of 14-substituted $14 H$-benzo $[a, j]$ xanthene derivatives by reacting various substituted aldehydes with $\beta$ naphthol. In this present work, the single use of the catalyst or solvent is not effective to produce a good yield of xanthene derivative, but when we use PEG-600 and basic bleaching earth clay catalyst together, their synergetic effect has been observed on the reaction in the form of reduced reaction times and higher yields compared with recently reported methods, which will give the method a wide scope in organic synthesis. Furthermore, the DFT analysis revealed that the electron-withdrawing functional group containing molecule pathway is more feasible over the electron-donating functional group containing molecule pathway due to the heightened electrophilic nature of the carbon atom of the aldehyde. The dehydration is the key step in this transformation and the presence of the catalyst with charged particles further eases the reaction by extracting protons from the substrates. The simplicity of the procedure, combined with the ease of recovery and reuse of the bleaching earth clay, make this method economic, benign and a waste-free chemical process.

Supplementary Materials: The following are available online at https: / www.mdpi.com/article/ 10.3390/catal11111294/s1: Figures S1-S32; Tables S1-S3.

Author Contributions: Conceptualization, S.T.A. and S.F.A.; methodology, S.T.A., G.M.B. and S.F.A.; formal analysis, P.V.R., V.T.K., R.V., M.A.H. and B.S.; investigation, G.M.B., P.V.R., R.V., M.A.H. and M.K.; resources, S.T.A. and P.V.R.; writing-original draft preparation, S.T.A., M.R.H. and S.F.A.; writing-review and editing, S.T.A., M.R.H., M.A.H. and S.F.A.; project administration, S.F.A. and M.R.H.; funding acquisition, M.R.H. All authors have read and agreed to the published version of the manuscript.

Funding: The authors would like to acknowledge the researchers' supporting project number (RSP2021/222), King Saud University, Riyadh, Saudi Arabia.

Data Availability Statement: Data are contained within the article and Supplementary Materials.

Acknowledgments: The authors would like to acknowledge the researchers supporting project number (RSP-2021/222), King Saud University, Riyadh, Saudi Arabia. The authors are thankful to Shigeru Yao, Institute for the creation of functional and structural materials, Fukuoka University, Japan for his advice and providing the computational resources.

Conflicts of Interest: The authors declare no conflict of interest.

\section{References}

1. Poupelin, J.; Saint-Ruf, G.; Foussard-blanpin, O.; Narcisse, G.; Uchida-Ernouf, G.; Lacroix, R. Synthesis and anti-inflammatory properties of bis(2-hydroxy,1-naphthyl) methane derivatives. Chem. Inf.-Dienst 1978, 9, 50.

2. Ion, R.M.; Planner, A.; Wiktorowicz, K.; Frackowiak, D. The incorporation of various porphyrins into blood cells measured via flow cytometry, absorption and emission spectroscopy. Acta Biochim. Pol. 1998, 45, 833-845. [CrossRef]

3. Ahmad, M.; King, T.A.; Ko, D.-K.; Cha, B.H.; Lee, J. Performance and photostability of xanthene and pyrromethene laser dyes in sol-gel phases. J. Phys. D: Appl. Phys. 2002, 35, 1473-1476. [CrossRef]

4. Callan, J.F.; de Silva, A.P.; Magri, D.C. Luminescent sensors and switches in the early 21st century. Tetrahedron 2005, 61, 8551-8588. [CrossRef]

5. Knight, D.W.; Little, P.B. The first efficient method for the intramolecular trapping of benzynes by phenols: A new approach to xanthenes. J. Chem. Soc., Perkin Trans. 1 2001, 1, 1771-1777. [CrossRef]

6. Jha, A.; Beal, J. Convenient synthesis of 12H-benzo[a]xanthenes from 2-tetralone. Tetrahedron Lett. 2004, 45, 8999-9001. [CrossRef]

7. Bekaert, A.; Andrieux, J.; Plat, M. New total synthesis of bikaverin. Tetrahedron Lett. 1992, 33, 2805-2806. [CrossRef]

8. Papini, P.; Cimmarusti, R. The action of formamide and formanilide on naphthols and on barbituric acid. Gazz. Chim. Ital. 1947, $77,142$.

9. Sen, R.N.; Sarkar, N.N. The condensation of primary alcohols with resorcinol and other hydroxyl aromatic compounds. J. Am. Chem. Soc. 1925, 47, 1079-1091. [CrossRef]

10. Koki, O.; Taketoshi, K. An Improved Synthesis of Dibenzoxanthene. Bull. Chem. Soc. Jpn. 1976, 49, 1167-1168.

11. Azizi, N.; Abbasi, F.; Abdoli-Senejani, M. Natural Acidic Ionic Liquid Immobilized on Magnetic Silica: Preparation and Catalytic Performance in Chemoselective Synthesis of Dicoumarols and Substituted Xanthene Derivatives. ChemSelect 2018, 3, 3797-3802. [CrossRef] 
12. Azizi, N.; Shirdel, F. Task specific dicationic acidic ionic liquids catalyzed efficient and rapid synthesis of benzoxanthenones derivatives. J. Mol. Liq. 2016, 222, 783-787. [CrossRef]

13. Xing, L.H.Y.; Xing, X.; Hui, Y. MCM-41@Schiff Base-Mn(OAc) 2 Catalyzed Synthesis of Xanthene Derivatives in Water. Chin. J. Org. Chem. 2018, 38, 912-918. [CrossRef]

14. Ko, S.; Yao, C.-F. Heterogeneous catalyst: Amberlyst-15 catalyzes the synthesis of 14 -substituted-14H-dibenzo[ $a, j]$ xanthenes under solvent-free conditions. Tetrahedron Lett. 2006, 47, 8827-8829. [CrossRef]

15. Saini, A.; Kumar, S.; Sandhu, J.S. A New LiBr-Catalyzed, Facile and Efficient Method for the Synthesis of 14-Alkyl or Aryl-14Hdibenzo $[a, j]$ xanthenes and Tetrahydrobenzo[b]pyrans under Solvent-Free Conventional and Microwave Heating. Synlett 2006, 2006, 1928-1932. [CrossRef]

16. Rajitha, B.; Sunil Kumar, B.; Thirupathi Reddy, Y.; Narsimha Reddy, P.; Sreenivasulu, N. Sulfamic acid: A novel and efficient catalyst for the synthesis of aryl-14H-dibenzo[ $[a, j]$ xanthenes under conventional heating and microwave irradiation. Tetrahedron Lett. 2005, 46, 8691-8693. [CrossRef]

17. Khosropour, A.R.; Khodaei, M.M.; Moghannian, H. A Facile, Simple and Convenient Method for the Synthesis of 14-Alkyl or Aryl-14-H-dibenzo[ $[a, j]$ xanthenes Catalyzed by pTSA in Solution and Solvent-Free Conditions. ChemInform 2005, 36, 955-958. [CrossRef]

18. Pasha, M.A.; Jayashankara, V.P. Molecular iodine catalyzed synthesis of aryl-14H-dibenzo[a,j]xanthenes under solvent-free condition. Bioorg. Med. Chem. Lett. 2007, 17, 621-623. [CrossRef]

19. Eshghi, H.; Bakavoli, M.; Moradi, $\mathrm{H}$. Fe( $\left(\mathrm{HSO}_{4}\right)_{3}$ : An efficient, heterogeneous and reusable catalyst for the synthesis of 14 -aryl- or alkyl-14H-dibenzo[a,j]xanthenes. Chin. Chem. Lett. 2008, 19, 1423-1426. [CrossRef]

20. Mirjalili, B.B.F.; Bamoniri, A.; Akbari, A. $\mathrm{BF}_{3} \cdot \mathrm{SiO}_{2}$ : An efficient alternative for the synthesis of 14 -aryl or alkyl-14Hdibenzo[a,j]xanthenes. Tetrahedron Lett. 2008, 49, 6454-6456. [CrossRef]

21. Kokare, N.D.; Sangshetti, J.N.; Shinde, D.B. Oxalic acid as a catalyst for efficient synthesis of bis-(indolyl)methanes, and 14-aryl14H-dibenzo[a,j]xanthenes in water. Chin. Chem. Lett. 2008, 19, 1186-1189. [CrossRef]

22. Madhav, J.V.; Kuarm, B.S.; Rajitha, B. Dipyridine cobalt chloride: A novel and efficient catalyst for the synthesis of 14-aryl 14H-dibenzo[a.j]xanthenes under solvent-free conditions. ARKIVOC 2008, 2008, 204-209. [CrossRef]

23. Bigdeli, M.A.; Heravi, M.M.; Hossein Mahdavinia, G. Wet cyanuric chloride catalyzed simple and efficient synthesis of 14 -aryl or alkyl-14-H-dibenzo[a,j]xanthenes. Catal. Commun. 2007, 8, 1595-1598. [CrossRef]

24. Bigdeli, M.A.; Heravi, M.M.; Mahdavinia, G.H. Silica supported perchloric acid $\left(\mathrm{HClO}_{4}-\mathrm{SiO}_{2}\right)$ : A mild, reusable and highly efficient heterogeneous catalyst for the synthesis of 14-aryl or alkyl-14-H-dibenzo[a,j]xanthenes. J. Mol. Catal. A Chem. 2007, 275, 25-29. [CrossRef]

25. Shaterian, H.R.; Ghashang, M.; Mir, N. Aluminium hydrogensulfate as an efficient and heterogeneous catalyst for preparation of aryl 14H-dibenzo[ $a, j]$ xanthene derivatives under thermal and solvent-free conditions. ARKIVOC 2007, 2007, 1-10. [CrossRef]

26. Kumar, P.S.; Kumar, B.S.; Rajitha, B.; Reddy, P.N.; Sreenivasulu, N.; Reddy, Y.T. A novel one pot synthesis of 14-aryl-14Hdibenzo[ $a, j]$ xanthenes catalyzed by Selectfluor ${ }^{\mathrm{TM}}$ under solvent free conditions. ARKIVOC 2006, 2006, 46-50. [CrossRef]

27. Ahmad, K.-Z.; Zahra, K.; Hadi, A.R. Structural investigation and preparation of 14-alkyl-14H-dibenzo [a,j] xanthenes revised. J. Korean Chem. Soc. 2002, 46, 541-544.

28. Sarma, R.J.; Baruah, J.B. One step synthesis of dibenzoxanthenes. Dyes Pigm. 2005, 64, 91-92. [CrossRef]

29. Shaterian, H.R.; Ghashang, M.; Hassankhani, A. One-pot synthesis of aryl 14H-dibenzo[a,j]xanthene leuco-dye derivatives. Dyes Pigm. 2008, 76, 564-568. [CrossRef]

30. Balogh, M.; Laszlo, P. Organic Chemistry Using Clays, 1st ed.; Springer: Berlin/Heidelberg, Germany, $1993 ;$ p. 184.

31. Acharya, A.; Kamble, R.; Patil, S.; Hese, S.; Yemul, O.; Patil, S.; Halale, S.; Dawane, B. “Green synthesis” of benzothiazepine library of indeno analogues and their in vitro antimicrobial activity. Chem. Pap. 2014, 68, 719-724. [CrossRef]

32. Kamble, R.D.; Jawadwar, G.V.; Patil, S.D.; Shrikant, V.H.; Hese, V.; Acharya, A.P.; Dawane, B.; Pekamwar, S. Bleaching earth clay ( $\mathrm{pH}$ 12.5): A novel and reusabl e catalyst for rapid synthesis of 7-Hydroxy 4-Styryl coumarin deri vatives and their antihelmintic activity. Org. Commun. 2013, 6, 95-101.

33. Kamble, R.D.; Dawane, B.S.; Yemul, O.S.; Kale, A.B.; Patil, S.D. Bleaching earth clay (pH 12.5): A green catalyst for rapid synthesis of pyranopyrazole derivatives via a tandem three-component reaction. Res. Chem. Intermed. 2013, 39, 3859-3866. [CrossRef]

34. Wasserscheid, P.; Keim, W. Ionic Liquids-New "Solutions" for Transition Metal Catalysis. Angew. Chem. Int. Ed. 2000, 39, 3772-3789. [CrossRef]

35. Sheldon, R. Catalytic reactions in ionic liquids. Chem. Commun. 2001, 2001, 2399-2407. [CrossRef] [PubMed]

36. Namboodiri, V.V.; Varma, R.S. Microwave-accelerated Suzuki cross-coupling reaction in polyethylene glycol (PEG). Green Chem. 2001, 3, 146-148. [CrossRef]

37. Parfitt, R.L.; Greenland, D.J. The Adsorption of Poly(Ethylene Glycols) on Clay Minerals. Clay Miner. 1970, 8, 305-315. [CrossRef]

38. Theng, B.K.G. Clay-Polymer Interactions: Summary and Perspectives. Clays Clay Miner. 1982, 30, 1-10. [CrossRef]

39. Frisch, M.J.; Trucks, G.W.; Schlegel, H.B.; Scuseria, G.E.; Robb, M.A.; Cheeseman, J.R.; Scalmani, G.; Barone, V.; Petersson, G.A.; Nakatsuji, H.; et al. Gaussian 16 Revision A. 03; Gaussian: Wallingford, CT, USA, 2016.

40. Hussain, M.A.; Mahadevi, A.S.; Sastry, G.N. Estimating the binding ability of onium ions with $\mathrm{CO}_{2}$ and $\pi$ systems: A computational investigation. Phy. Chem. Chem. Phy. 2015, 17, 1763-1775. [CrossRef] [PubMed] 